\title{
ANTINEURODEGENERATIVE ACTIVITY OF MICROALGAE DUNALIELLA SALINA IN RATS WITH ALZHEIMER'S DISEASE
}

\author{
FAROUK K EL-BAZ ${ }^{1 *}$, HANAN F ALY ${ }^{2}$, WAGDY KB KHALIL ${ }^{3}$, HODA F BOOLES ${ }^{3}$, GAMILA H ALI ${ }^{4}$
}

${ }^{1}$ Department of Plant Biochemistry, National Research Centre, Dokki, Giza, Egypt. ${ }^{2}$ Department of Cell Biology, National Research Centre, Dokki, Giza, Egypt. ${ }^{3}$ Department Therapeutic Chemistry, National Research Centre, Dokki, Giza, Egypt. ${ }^{4}$ Department Water Pollution Research, National Research Centre, Dokki, Giza, Egypt. Email: fa_elbaz@hotmail.com

Received: 31 July 2016, Revised and Accepted: 10 August 2016

\section{ABSTRACT}

Objective: The present study is aimed to investigate the promising action of Dunaliella salina extract as a natural protector against Alzheimer's disease (AD) and reported to possess a variety of activities, including antioxidant effects due to its ability to create large amount of carotenoids.

Methods: D. salina is a type of halophile green microalgae was used in the present study. 50 male rats were used in this study, where aluminum chloride was orally administered to induce $\mathrm{AD}$ in a dose of $100 \mathrm{mg} / \mathrm{kg}$, daily for 6 weeks. Al-intoxicated rats treated orally daily with $D$. salina ethanolic extract for 6 weeks in a dose of $150 \mathrm{mg} / \mathrm{kg}$ b.wt., whereas standard anti-Alzheimer drug donepezil tartrate was administered at the dose of $10 \mathrm{mg} / \mathrm{kg}$ b.wt./day for 6 consecutive weeks. The anti-Alzheimer properties of $D$. salina extract were achieved through measuring the calmodulin (CaM) level, paraoxonase 1 (PON1) activity, the antiapoptotic marker (Bcl2), brain-derived neurotrophic factor (BDNF), the generation of the DNA adducts (8-hydroxy-2-deoxyguanosine [8-OHdG]/2-deoxy guanosine [2-dG]), and alteration in the expression of amyloid precursor protein, $\beta$-site APP-cleaving enzyme 1 (BACE1), and $\beta$-site APP-cleaving enzyme 2 (BACE2) in AD rats.

Results: The current results demonstrated that supplementation of AD rats with $D$. salina extract-enhanced CaM level, and increased PON1 activity, upregulated $\mathrm{Bcl} 2$ and BDNF, decreased the levels of DNA adducts (8-OHdG/2-dG), and suppressed the alterations of the expression levels of APP, BACE1, and BACE2-m RNAs as compared with those in AD rats.

Conclusion: It could be concluded that the biological activity of $D$. salina extract might be regulated by 9 -cis b-carotene protecting the brain cells from the oxidative stress in $\mathrm{AD}$ rats.

Keywords: Dunaliella salina, Calmodulin, Paraoxonase 1, Bcl2, Brain-derived neurotrophic factor, Alzheimer's disease, DNA adduct, Amyloid precursor protein.

(C) 2017 The Authors. Published by Innovare Academic Sciences Pvt Ltd. This is an open access article under the CC BY license (http://creativecommons. org/licenses/by/4. 0/) DOI: http://dx.doi.org/10.22159/ajpcr.2017.v10i1.14419

\section{INTRODUCTION}

Alzheimer's disease (AD) is characterized by extracellular deposition of $\beta$-amyloid plaques, neurofibrillary tangles, loss of synapses, neurons, and vacuolar degeneration. $\mathrm{AD}$, the fourth leading cause of death in the USA, also characterized by neuropsychiatric symptoms including apathy, depression, aggression, agitation, sleep disruption, and psychosis [1] The amyloid precursor protein and the microtubule-associated protein, tau, are two major proteins involved in AD pathology. The $\beta$-amyloid protein is produced from the amyloid $\beta$-protein precursor (APP) by two sequential proteolytic cleavages enzymes called secretases [2] Studies also showed that the products of oxidative stress were found in neurofibrillary tangles and senile plaques in AD $[3,4]$. Therefore, special interest has been focused in establishing the therapeutic role of antioxidants in neurodegenerative disease such as AD. The natural antioxidants vitamin $\mathrm{E}, \mathrm{C}$, and $\beta$-carotene considerably decreased the symptoms associated with $\mathrm{AD}[5]$

Among all natural sources studied to date, Dunaliella possesses the highest content of 9 -cis $\beta$-carotene reaching levels up to $100 \mathrm{~g} / \mathrm{kg} \mathrm{b.wt}$. $\beta$-carotene-rich Dunaliella powder has been commercially exploited in many countries since the 1980s [6-10]. Dunaliella salina is a type of halophile green microalgae especially contains potential bioactive compounds for recent biomedical and pharmaceutical values [11]. It has been reported that due to the abundance of $\beta$-carotene, which is an antioxidant as well as a vitamin A precursor, D. salina is a popular pro-vitamin A food supplement and cosmetic additive [12]. It was demonstrated that $D$. salina exhibits strong protective effects on ultraviolet $\mathrm{B}$ radiation-induced corneal oxidative damage in mice, which seems to be caused by the increase of antioxidant enzyme activity and the inhibition of lipid peroxidation. Research performed at the Cancer Research Centre of Hawaii showed that D. salina contains a certain type of $\beta$-carotene called 9 -cis $\beta$-carotene, which is up to ten times stronger at preventing cancer than ordinary $\beta$-carotene [13]. Clinical studies showed that whole dried $D$. salina cells are an effective source of bioavailable carotenoids and 14 weeks of supplementation with $D$. salina can produce favorable shifts oxidative mutagens in humans [14].

Although several works have been focused on the AD therapy, D. salina alga has been not investigated yet. Therefore, the present study aimed to evaluate the regulating role of $D$. salina alga against neurodegenerative disorders in rats.

\section{METHODS}

Chemicals

Donepezil and all chemicals were purchased from Sigma Co. (USA) and aluminum chloride from BDH Laboratory Supplies, Poole (UK). TRIzol reagent was bought from Invitrogen (Germany). The reverse transcription (RT) and polymerase chain reaction (PCR) kits were obtained from Fermentas (USA). SYBR Green Mix was purchased from Stratagene (USA).

\section{Collection of $D$. salina and ethanolic extract preparation}

D. salina (Strain No. NIES-2257) was isolated by spreading $0.1 \mathrm{ml}$ of water samples collected from the Egyptian Company for Salts and Mineral (EMISAL) effluent ponds using BG11 media [15] for algal isolation with addition of $\mathrm{NaCl}$ (100 g/l) into Petri dishes containing $1.5 \%$ agar for solidification. Single colonies of algae were then recultivated in the specified liquid media as nonaxenic 
batch cultures $(50 \mathrm{ml})$ at $25 \pm 2^{\circ} \mathrm{C}$ and $24 \mathrm{hr}$ with continuous white fluorescent lamp intensity $\approx 2500$ Lux. Cultivation was carried out on an open pond with a capacity of $70 \mathrm{~L}$ containing $55 \mathrm{~L}$ of growth media. After cultivation, D. salina biomass was harvested using electro flocculation method.

About $100 \mathrm{~g}$ of D. salina powder were soaked in ethanol (80\%) and shacked on shaker (Heidolph UNIMAX 2010) for $48 \mathrm{hr}$ at $150 \mathrm{rpm}$. The extract was filtered using a Buchner funnel and Whatman No. 4 filter paper and the algal residue was reextracted with the addition of fresh ethanol $(80 \%)$ for another two times. Combined filtrates were concentrated using Rotary evaporator (Heidolph-Germany) at $40^{\circ} \mathrm{C}$ under vacuum. The resulting dry extract was evaporated on a rotary vacuum evaporator to dryness [16]. The dry extract was stored at $-20^{\circ} \mathrm{C}$ in freeze and kept for further analysis.

\section{Experimental animals}

Animals

Male Wistar rats (180-200 g) procured from Central Animal House, National Research Centre (NRC), were used. Animals were acclimatized to the laboratory conditions at room temperature before the experimentation. Animals were kept under standard conditions of a $12 \mathrm{hr}$ light/dark cycle with food and water ad-libitum in plastic cages with soft bedding. All the experiments were carried out between 9.00 and $15.00 \mathrm{hr}$. The protocol was approved by the NRC Ethics Committee Guidelines for the use and care of animals.

\section{Drugs and treatment schedule}

Aluminum chloride $\left(\mathrm{AlCl}_{3}\right.$ ) ( $\mathrm{CDH}$, India) solutions were made freshly at the beginning of each experiment. For oral administration, $\mathrm{AlCl}_{3}$ was dissolved in drinking water and administered in a dose of $100 \mathrm{mg} / \mathrm{kg}$, p.o. was administered to rats daily for 6 weeks $0.5 \mathrm{ml} / 100 \mathrm{~g}$ body weight [17]. Donepezil tartrate $(10 \mathrm{mg} / \mathrm{kg}$ b.wt./day) diluted in ultrapure water daily for 6 weeks [18]. Animals were randomized into five groups (50 adult male Sprague-Dawley rats) based on their body weight. Each group had 10 numbers of animals. The groups were as follows:

Group 1: Normal control rats.

Group 2: Normal control rats treated with D. salina.

Group 3: Serving as Al-intoxicated rats were orally administered with $\mathrm{AlCl}_{3}$.

Group 4: Al-intoxicated rats treated orally daily with $D$. salina ethanolic extract for 6 weeks in a dose of $150 \mathrm{mg} / \mathrm{kg}$ b.wt. [19].

Group 5: Al-intoxicated rats orally administered daily with standard drug.

\section{Brain tissue sampling and preparation}

At the end of the experiment, the rats were fasted overnight, subjected to anesthesia with diethyl ether and sacrificed. The whole brain of each rat was rapidly dissected, washed with isotonic saline, and dried on filter paper. Each brain was divided sagittally into two portions. The first portion was weighed and homogenized in ice-cold medium containing $50 \mathrm{mMTris} / \mathrm{HCl}$ and $300 \mathrm{mM}$ sucrose at $\mathrm{pH} 7.4$ to give a $10 \%$ $(\mathrm{w} / \mathrm{v})$ homogenate [20]. This homogenate was centrifuged at $1400 \times g$ for 10 minutes at $4^{\circ} \mathrm{C}$. The supernatant was stored at $-80^{\circ} \mathrm{C}$ and used for biochemical analyses that included antioxidant enzyme CaM and PON1 level. The ethical conditions were applied such that the animals suffered no pain at any stage of the experiment, and the study was approved by the Ethics Committee of the NRC. Animals were disposed of in bags provided by the Committee of Safety and Environmental Health, NRC.

\section{Biochemical analyses}

The activity of CaM as an activator of cAMP phosphodiesterase was assayed in brain tissue homogenate by the spectrophotometric method according to Garg et al. [21] while, PON1 was determined in brain tissue by ELIZA technique method. Brain Bcl2 was determined by ELISA technique according to the method of Barbareschi et al. [22].
Brain-derived neurotrophic factor (BDNF) was determined by ELISA technique according to the method of Barakat-Walter [23].

Determination of 8-hydroxy-2-deoxyguanosine (8-0HdG)/2-deoxy guanosine (2-dG) in brain tissues by high-performance liquid chromatography (HPLC)

DNA was extracted from rat brain by homogenization in buffer containing $1 \%$ sodium dodecyl sulfate, $10 \mathrm{mM}$ Tris, $1 \mathrm{mM}$ EDTA ( $\mathrm{pH}$ 7.4), and an overnight incubation in $0.5 \mathrm{mg} / \mathrm{ml}$ proteinase $\mathrm{K}$ at $55^{\circ} \mathrm{C}$. Homogenates were incubated with RNase $(0.1 \mathrm{mg} / \mathrm{ml})$ at $50^{\circ} \mathrm{C}$ for 10 minutes and extracted with chloroform/isoamyl alcohol. The extracts were mixed with $3 \mathrm{M}$ sodium acetate and two volumes of $100 \%$ ethanol to precipitate DNA at $-20^{\circ} \mathrm{C}$. The samples were washed twice with $70 \%$ ethanol, air-dried for 15 minutes, and dissolved in $100 \mu \mathrm{l}$ of $10 \mathrm{mM}$ Tris/1 mM EDTA (pH 7.4) [24]. DNA was then digested and the adduct 8-OHdG was measured with HPLC equipped with a Coul Array system (Model 5600). Analytes were detected on two coulometric array modules, each containing four electrochemical sensors attached in series, which allows identification targets based on reduction potential. The UV detection was set to $260 \mathrm{~nm}$. The HPLC was controlled and the data acquired and analyzed using Coul Array software. The mobile phase was composed of $50 \mathrm{mM}$ sodium acetate $5 \%$ methanol at $\mathrm{pH}$ 5.2. Electrochemical detector potentials for 8- OHdG and 2-dG were $120 / 230 / 280 / 420 / 600 / 750 / 840 / 900 \mathrm{mV}$, and the flow rate was $1 \mathrm{ml} /$ minute.

\section{Gene expression analysis}

Extraction of total RNA and complementary DNA (cDNA) synthesis

Liver tissues of male rats were used to extract the total RNA using TRIzol ${ }^{\circledR}$ Reagent (Invitrogen, Germany) Kit. The isolation method was carried out according to the manufacturer's instructions of the above kit. Approximately, $50 \mathrm{mg}$ of the liver tissues were mixed with some drops of liquid nitrogen and homogenized in $1 \mathrm{ml}$ of TRIzol ${ }^{\circledR}$ Reagent in autoclaved mortar. Afterward, total RNA was dissolved and preserved in diethylpyrocarbonate-treated water up to use.

To assess the RNA yield and purity of the total RNA, RNAse-free DNAse I (Invitrogen, Germany) was used to digest DNA contamination. A small drop of isolated RNA was examined photospectrometrically at $260 \mathrm{~nm}$. The purity of total RNA was determined between 1.8 and 2.1 to be good purified when it examined by photospectrometer at the $260 / 280 \mathrm{~nm}$ ratio. To avoid RNA damaging, aliquots of RNA were prepared after isolation for either RT reaction or otherwise for storing at $-80^{\circ} \mathrm{C}$ up to use.

To synthesize the cDNA isolated RNA from liver tissues was reverse transcribed into cDNA. The reaction volume was carried out in $20 \mu \mathrm{l}$. The reaction volume was prepared according to the instructions of the RevertAid TM First Strand cDNA Synthesis Kit (MBI Fermentas, Germany). The RT reaction was performed for 10 minutes at $25^{\circ} \mathrm{C}$. Afterward, the tubes of the reaction were put in thermocycler machine for 60 minutes at $42^{\circ} \mathrm{C}$, and then, the reaction was terminated for 5 minutes at $99^{\circ} \mathrm{C}$. The PCR products containing the cDNA were kept at $-20^{\circ} \mathrm{C}$ up to use for DNA amplification $[25,26]$.

\section{Quantitative real-time PCR ( $q R T$-PCR)}

A step one real-time PCR system (Applied Biosystem, USA) was used to assess the copy of the cDNA of male rats to detect the expression values of the tested genes. To perform the PCR reaction, a volume of $25 \mu \mathrm{l}$ of reaction mixtures was prepared containing $12.5 \mu \mathrm{l}$ of SYBR ${ }^{\circledR}$ green (TaKaRa, Biotech. Co. Ltd.), $0.5 \mu \mathrm{l}$ of $0.2 \mu \mathrm{M}$ forward and reverse primers, $6.5 \mu \mathrm{l}$ DNA-RNA free water, and $2.5 \mu \mathrm{l}$ of the synthesized cDNA. The cDNA was propagated using reaction program consisted of 3 steps. In the first step, the PCR tubes were incubated at $95^{\circ} \mathrm{C}$ for 3 minutes. In the second step, the reaction program consisted of 50 cycles. Each cycle of them consisted of 3 substeps: (a) 15 seconds at $95^{\circ} \mathrm{C}$; (b) 30 seconds at $60^{\circ} \mathrm{C}$; and (c) 30 seconds at $72^{\circ} \mathrm{C}$ in the third step; the reaction program consisted of 71 cycles. The first cycle of them started 
at $60^{\circ} \mathrm{C}$ for 10 seconds, and then, the followed cycles increased about $0.5^{\circ} \mathrm{C}$ every 10 seconds up to $95^{\circ} \mathrm{C}$. A melting curve of the reaction was performed for each qRT-PCR termination at $95^{\circ} \mathrm{C}$ to assess the quality of the primers. To verify that the reaction of the qRT-PCR does not have any contamination PCR tubes containing nontemplate control were used. The sequences of the specific primer of the genes used are listed in Table 1 . The relative quantification of the target genes to the reference ( $\beta$-actin) was determined using the $2-\Delta \Delta \mathrm{CT}$ method.

\section{Statistical analyses}

Data were analyzed by one-way analysis of variance using the Statistical Package for the Social Sciences program, version 11 followed by least significant difference to compare significance between groups. The difference was considered significant when $\mathrm{p} \leq 0.05$.

\section{RESULTS AND DISCUSSION}

\section{Effect of $D$. salina extract on CaM level and PON1 activity}

Table 2 showed the effect of $D$. salina extract on AD-induced rats, through measuring CaM and PON1 levels in rats' brain tissue. The results showed an insignificant change in CaM level in normal rats treated with $D$. salina extract comparing with normal control rats. While a significant increase in PON1 activity as compared to normal untreated one was observed with percentage $15.32 \%$. AD-induced rats showed a significant decrease in CaM level (62.41\%), and PON1 activity (27.36\%) comparing with normal control. Treatment of intoxicated rats with $D$. salina extract demonstrated a significant increase in CaM with improvement percentage $32.62 \%$, whereas an insignificant change in PON1 activity $(34.47 \%)$ as compared to normal control rats was detected. Standard drug recorded a significant decrease in CaM level with amelioration percentage $25.53 \%$, whereas insignificant change in PON1 activity $(17.73 \%)$ comparing with normal control rats was recorded.

The present results demonstrated a significant reduction in both CaM and PON1 activity in AD rats. In accordance with the present

Table 1: Primer sequences used for qPCR

\begin{tabular}{lll}
\hline Gene & Primer sequence $\left(\mathbf{5}^{\prime}-\mathbf{3}^{\prime}\right)$ & References \\
\hline APP & F: ACT GGC TGA AGA AAG TGA CAA T & Stein and \\
& R: AGA GGT GGT TCG AGT TCC TAC A & Johnson [27] \\
BACE1 & F: GCG CTT GCC ATG TGC AC & Luo et al. [28] \\
& R: TGC CGT AAC AAA CGG ACC TT & \\
BACE2 & F: AAA TTT CTG GGC CCT TTT CC & Luo et al. [28] \\
& R: GGG CTC ATT CAG AGC CTG TG & \\
$\beta$-actin & F: GGAGATTACTGCCCTGGCTCCTA & Deng et al. [29] \\
& R: GACTCATCGTACTCCTGCTGCTG &
\end{tabular}

F: Forward primer, R: Reverse primer, APP: Amyloid $\beta$-protein precursor, BACE1: $\beta$-site APP-cleaving enzyme 1, BACE2: $\beta$-site APP-cleaving enzyme 2 , qPCR: Quantitative polymerase chain reaction

Table 2: Effect of $D$. salina extract on CaM level and PON1 activity

\begin{tabular}{lll}
\hline \multirow{2}{*}{ Groups } & \multicolumn{2}{l}{ Parameters } \\
\cline { 2 - 3 } & CaM (ng/ml) & PON1 (U/L) \\
\hline Normal control & $2.80 \pm 0.13^{\mathrm{a}}$ & $210.90 \pm 10.20^{\mathrm{a}}$ \\
D. salina treated normal control & $2.76 \pm 0.10^{\mathrm{a}}$ & $243.20 \pm 10.50^{\mathrm{c}}$ \\
\% change & 3.16 & 15.32 \\
AD & $1.06 \pm 0.95^{\mathrm{b}}$ & $153.20 \pm 12.13^{\mathrm{d}}$ \\
\% change & 62.41 & 27.36 \\
D. salina treated AD rats & $1.98 \pm 0.52^{\mathrm{c}}$ & $225.90 \pm 14.20^{\mathrm{a}}$ \\
\% change & 29.78 & 7.11 \\
\% of improvement & 32.62 & 34.47 \\
Standard drug treated AD rats & $1.78 \pm 0.42^{\mathrm{d}}$ & $190.59 \pm 11.50^{\mathrm{a}}$ \\
\% change & 36.87 & 9.63 \\
\% of improvement & 25.53 & 17.73 \\
\hline
\end{tabular}

Data are means \pm SD of 10 rats in each group. Unshared letters between groups are the significance value at $\mathrm{P} \leq 0.05$. SD: Standard deviation, $D$. salina: Dunaliella salina, AD: Alzheimer's disease, PON1: Paraoxonase 1, CaM: Calmodulin result McLachlan et al. [30] declared, the calcium binding proteins in the Alzheimer-induced rats, frontal, temporal, parietal cortex, and subjacent white matter CaM content was significantly reduced (66\%). The author added that CaM extracted from temporal cortex also demonstrated reduced efficacy as an activator of 3',5' cyclic nucleotide phosphodiesterase. Reduced concentrations of these important proteins may affect calcium homeostasis and the regulation of a large number of calcium-mediated brain functions. It was suggested that an imbalance of calcium levels in cells precedes the signaling pathway malfunctions and neuronal deterioration observed in neurodegenerative diseases [31].

Calmodulin binding proteins linked to the formation of amyloid plaques. The "amyloid hypothesis" is arguably the predominant hypothesis for the symptoms and progression of AD. CaM is significantly decreased in the brains of $\mathrm{AD}$ individuals [30]. In spite of this, the existing CaM can interact with several proteins in the amyloid pathway. It is based on the aggregation of $A \beta$ peptides plus a multitude of other components to form extracellular amyloid plaques in the brains of AD sufferers [31].

Regarding PON1, it exerts a potent protective role in vivo against oxidative $(\mathrm{OxS})$-induced damage [32,33]. Only relatively few studies have examined the relationship between biochemical determinants of this HDL-associated protein and dementia, the decrease in antioxidant protection by PON-1 might be one of the reasons for the exacerbation of OxS observed in dementia patients [34-37]. In addition, PON1 is an enzyme with multiple physiological functions and roles. Relevant to this notion, studies conducted in knockout mice have shown that PON-1 may serve as a key determinant in the detoxification of organophosphate pesticides that, in turn, are regarded as strong risk factors for neurological diseases, such as ate onset Alzheimer's disease (LOAD) and Parkinson's disease [38].

Effect of $D$. salina extract treatment on brain antiapoptotic marker (Bcl2) and BDNF in Al-intoxicated rats

Table 3 declared in a significant change in the antiapoptotic marker (Bcl-2) and BDNF in normal rats treated with D. salina as compared to normal untreated rats. AD rats demonstrated a significant decrease in Bcl-2 and BDNF with percentages of 57.46 and $43.11 \%$, respectively. Treatment of AD-induced rats with $D$. salina extract recorded significant reduction in both $\mathrm{Bcl} 2$ and $\mathrm{BDNF}$ levels with amelioration $33.65 \%$ and $30.26 \%$, respectively, compared with $27.20 \%$ and $24.70 \%$, respectively, for standard drug.

Respecting to the Bcl2 and BDNF levels, the present data showed a significant decrease in brain levels of $\mathrm{Bcl} 2$ and BDNF in Al-intoxicated rats. $\mathrm{AlCl}_{3}$ decreased $\mathrm{Bcl} 2$ expression and increased proapoptotic marker (Bax) expression in the rat hippocampus. Altered $\mathrm{Bax} / \mathrm{Bcl} 2$ ratio

Table 3: Effect of $D$. salina extract treatment on brain antiapoptotic marker (Bcl-2) and BDNF in Al-intoxicated rats

\begin{tabular}{lll}
\hline Groups & Parameters & \\
\cline { 2 - 3 } & $\begin{array}{l}\text { BCl2 } \\
\text { (pg/mg }\end{array}$ & $\begin{array}{l}\text { BDNF } \\
\text { (pg/mg }\end{array}$ \\
& protein) & protein) \\
\hline Normal control & $118.00 \pm 6.94^{\mathrm{a}}$ & $90.00 \pm 4.00^{\mathrm{a}}$ \\
D. salina treated normal control & $119.00 \pm 7.96^{\mathrm{a}}$ & $89.23 \pm 3.22^{\mathrm{a}}$ \\
\% change & 0.85 & 0.86 \\
AD & $50.20 \pm 4.10^{\mathrm{b}}$ & $51.20 \pm 5.20^{\mathrm{b}}$ \\
\% change & 57.46 & 43.11 \\
D. salina treated AD rats & $89.90 \pm 3.17^{\mathrm{c}}$ & $78.43 \pm 2.11^{\mathrm{c}}$ \\
\% change & 23.81 & 12.86 \\
\% of improvement & 33.65 & 30.26 \\
Standard drug treated AD rats & $82.30 \pm 3.17^{\mathrm{c}}$ & $73.43 \pm 2.11^{\mathrm{c}}$ \\
\% change & 30.25 & 18.41 \\
\% of improvement & 27.20 & 24.70 \\
\hline
\end{tabular}

Data are means \pm SD of 10 rats in each group. Unshared letters between groups are the significance value at $\mathrm{p} \leq 0.05$. SD: Standard deviation, D. salina: Dunaliella salina, AD: Alzheimer's disease, BDNF: Brain-derived neurotrophic factor 
is critical to Al-induced apoptosis leading to activation of caspase-3 and release of cytochromec [39,40]. Kumar et al. [17] reported that $\mathrm{Al}$ increases p53 protein expression by activating p38 MAPK to initiate apoptosis and this is accompanied by a marked inhibition of Bcl-2 and increased Bax expression. Takuma et al. [41] showed marked decrease in the BDNF mRNA level in the hippocampus due to ovariectomy in mice. Disruption of the pro-inflammatory cytokine/neurotrophin balance by Al plays an important role in the neurodegenerative disease [42].

\section{Effect of $D$. salina extract on the DNA adducts}

Determination of the 8-OHdG generation in brain tissues of AD-induced rats' genome following $D$. salina extract treatment is summarized in Fig. 1. Fig. 1 showed that $\mathrm{AD}$-induced rats revealed a significant increase in the 8-OHdG/2-dG ratio compared with those in control rats. However, the results showed that $8-\mathrm{OHdG} / 2-\mathrm{dG}$ ratio following treatment of AD-induced rats with $D$. salina extract decreased significantly compared with those in $\mathrm{AD}$-induced rats and reached relatively similar to that of the control group. Moreover, the ratio of $8-\mathrm{OHdG} / 2-\mathrm{dG}$ generation in $\mathrm{AD}$ rats treated with donepezil $(10 \mathrm{mg} / \mathrm{kg})$, as reference drug for $\mathrm{AD}$ treatment, was decreased significantly compared with those in AD rats (Fig. 1).

The results of the present study revealed that $\mathrm{AD}$ rats exhibited significantly high levels of DNA adducts in the form of the ratio of 8-OHdG/2-dG and high expression levels of AD-related genes (APP, BACE1, and BACE2). These results are in the same line of Guix et al. [43], who reported that levels of brain nitric oxide (BNO) which is responsible for increase the oxidation and DNA damage are increasing in neurodegenerative diseases such as $\mathrm{AD}$, stroke, and Parkinson's diseases due to the formation of highly reactive peroxynitrite. Moreover, Dorheim et al. [44]reported that the increase in the levels of BNO in AD patients may result from the activation of NO synthesis, in which it is also increasing in the brain tissue of AD patients, suggesting that BNO may play a role in neuronal cell degeneration in the $\mathrm{AD}$ disease.

\section{Effect of the $D$. salina extract on the expression of AD genes}

The expression levels of the genes encoding AD enzymes including APP and $\beta$-site APP-cleaving enzyme 1 and 2 (BACE1 and BACE2) in brain tissues of AD rats were quantified by real-time RT-PCR (Figs. 2-4). The results revealed that $A D$-induced rats revealed a significant increase in the expression of APP, BACE1, and BACE2 genes compared with those in control rats. The percentages of the mRNA expression of APP, BACE1, and BACE2 genes in AD rats were $513.5 \%, 602.8 \%$, and $332.5 \%$, respectively, compared with those in control rats (Figs. 2-4). In contrary, the expression levels of APP, BACE1, and BACE2 genes decreased significantly in $\mathrm{AD}$ rats treated with $D$. salina extract compared with those in AD rats. The percentage of the mRNA expression of APP, BACE1, and BACE2 genes in AD rats treated with D. salina extract decreased to $234.5 \%, 311.1 \%$, and $183.1 \%$, respectively, compared with those in $\mathrm{AD}$ rats (Figs. 2-4). Moreover, the percentage of the mRNA expression of APP, BACE1, and BACE2 genes decreased to $226.9 \%, 255.6 \%$, and $166.2 \%$, respectively, in $\mathrm{AD}$ rats treated with donepezil compared with those in $\mathrm{AD}$ rats.

Some reports suggested that oxidative stress and DNA damage are associated with signal transduction pathways of $\mathrm{N}$-methyl-D-aspartate receptors (NMDA), in which they are glutamate receptors and ion channel protein found in nerve cells receptors. In this pathway, the activation of NMDA receptors leads to increased intracellular calcium in the postsynaptic neuron, which, in turn, binds to CaM and triggers the activation of the NOS enzyme opening a gate for the electron flux into the active center of the NOS in brain tissue $[45,46]$. Thus, it gives rise to the elevated levels of BNO that are apparently involved in neurodegeneration by different mechanisms, including oxidative stress and activation of intracellular signaling mechanisms [47].

The present study exhibited that treatment of AD rats with $D$. salina extract decreased significantly the levels of DNA adducts and the expression levels APP, BACE1, and BACE2 genes. The formation of

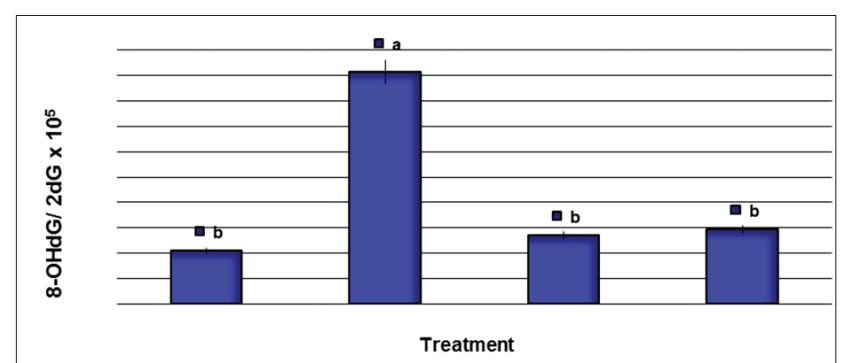

Fig. 1: Generation of 8-hydroxy-2-deoxyguanosine (8-0HdG) in the brain tissues of Alzheimer's disease-induced rats treated with Dunaliella salina extract. DNA damage was expressed as the ratio of oxidized DNA base (8-0HdG) to nonoxidized base (2-deoxy guanosine) in brain DNA. Data are presented as mean \pm standard error of mean, ${ }^{a, b, c}$ followed by different superscripts are significantly different $(p \leq 0.05)$

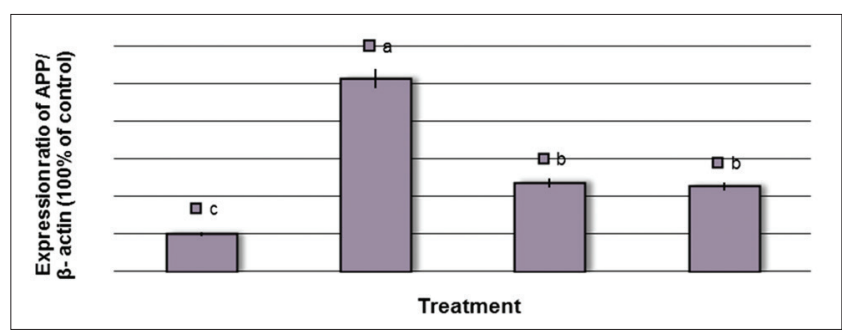

Fig. 2: Expression levels of amyloid $\beta$-protein precursor gene in brain tissues of Alzheimer's disease-induced rats treated with Dunaliella salina extract. Data are presented as mean \pm standard error of mean, ${ }^{a, b}, \mathrm{c}$ followed by different superscripts are significantly different $(p \leq 0.05)$

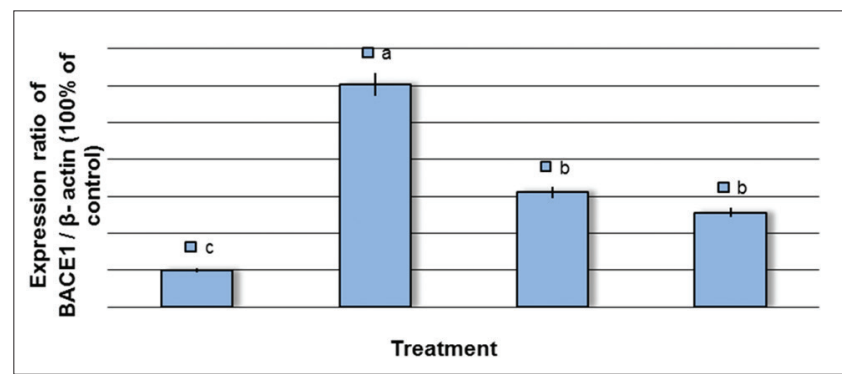

Fig. 3: Expression levels of BACE1 gene in brain tissues of Alzheimer's disease-induced rats treated with Dunaliella salina extract. Data are presented as mean \pm standard error of mean, a,b,cfollowed by different superscripts are significantly different $(p \leq 0.05)$

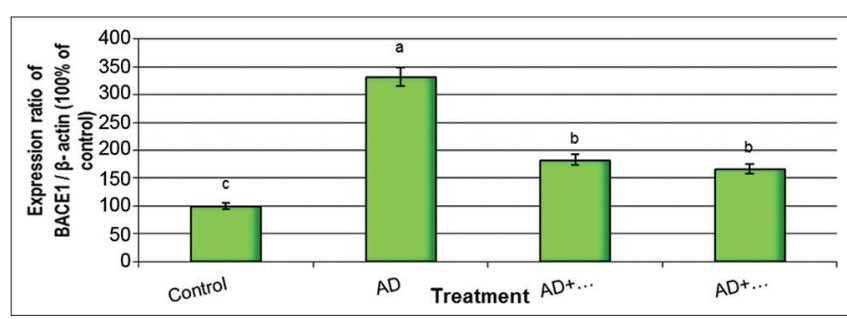

Fig. 4: Expression levels of BACE2 gene in brain tissues of Alzheimer's disease-induced rats treated with Dunaliella salina extract. Data are presented as mean \pm standard error of mean, ${ }^{a, b, c}$ followed by different superscripts are significantly different ( $p \leq 0.05)$ 
Alzheimer's A $\beta$ peptide is initiated when APP is cleaved by the BACE1 and BACE2 enzymes [48]. It has been reported that $D$. salina is known to have high carotenoid content [19]. Moreover, D. salina extracts are shown to contain high levels of antioxidant activity in the both in vitro and in vivo studies [49]. These studies demonstrated that the ameliorative effect of $D$. salina is attributed to the 9-cis $\beta$-carotene content [49].

Several studies revealed that 9 -cis $\beta$-carotene inhibited the chromosomal breaks (micronucleus formation) in the lymphocytes of human in vitro [49]. Moreover, other reports indicating that the therapeutic role of 9-cis $\beta$-carotene is attributed to its antioxidant properties and inhibition of the metabolic pathway of the most pro-mutagens $[50,51]$. Thus, the results of the current work could be suggested that $D$. salina extract is able to DAN adducts and alterations of AD-related genes through the protective pathway of 9-cis $\beta$-carotene which protect the cells from the oxidative stress occurred in the degenerative cells of $\mathrm{AD}$ rats.

Moreover, several reports revealed that $\beta$-carotene extracted from Dunaliella sp., which contain high levels of bioavailable 9-cis, have in fact provided verification of a lower incidence of several kinds of cancer and degenerative disorders [50].

\section{CONCLUSION}

D. salina extract is capable to suppress the DNA adducts and decrease the alterations in the AD-related genes in $\mathrm{DA}$ rats. The biological activity of $D$. salina extract is might be regulated by 9 -cis $\beta$-carotene which it is coinciding with degenerative protection in the oxidative stressed cells in $\mathrm{AD}$ patients.

\section{ACKNOWLEDGMENT}

This work was supported and funded by the project entitled "Biodiesel production from algae as a renewable energy source." Funding organization: Research Development and Innovation program (RDI), Funding Program: EU-Egypt Innovation Fund, 2014-2016.

\section{REFERENCES}

1. Kaur K, Kaur R, Kaur M. Recent advances in Alzheimer's disease: Causes and treatment. Int J Pharm Pharm Sci 2016;8:8-15.

2. Nunan J, Small DH. Regulation of APP cleavage by alpha-, beta- and gamma-secretases. FEBS Lett 2000;483(1):6-10.

3. Manczak M, Anekonda TS, Henson ED, Park BS, Quinn J, Reddy PH. Mitochondria are a direct site of A beta accumulation in Alzheimer's disease neurons: Implications for free radical generation and oxidative damage in disease progression. Hum Mol Genet 2006;15(9):1437-49.

4. Zhu XW, Raina AK, Lee HG, Casadesus G, Smith MK, Perry G. Oxidative stress signaling in Alzheimer's disease. Brain Res 2004;1000(1-2):32-9.

5. Sano M, Ernesto C, Thomas RG, Klauber MR, Schafer K, Grundman M, et al. A controlled trial of selegiline, alpha-tocopherol, or both as treatment for Alzheimer's disease. The Alzheimer's disease cooperative study. N Engl J Med 1997;336(17):1216-22.

6. Hsu YW, Tsai CF, Chang WH, Ho YC, Chen WK, Lu FJ. Protective effects of Dunaliella salina-a carotenoid-rich alga, against carbon tetrachloride-induced hepatoxicity in mice. Food Chem Toxicol 2008;46(10):3311-7.

7. Ben-Amotz A. Dunaliella $\beta$-carotene: From science to commerce. In Enigmatic Microorganisms and Life in Extreme Environments. The Netherlands: Kluwer; 1999. p. 401-10.

8. Raja R, Hemaiswarya S, Rengasamy R. Exploitation of Dunaliella for $\beta$-carotene production. Appl Microbiol Biotechnol 2007;74:517-23.

9. Coesel SN, Baumgartner AC, Teles LM, Ramos AA, Henriques NM, Cancela L, et al. Nutrient limitation is the main regulatory factor for carotenoid accumulation and for Psy and Pds steady state transcript levels in Dunaliella salina (Chlorophyta) exposed to high light and salt stress. Mar Biotechnol 2008;10(5):602-11.

10. Mogedas B, Casal C, Forján E, Vílchez C. Beta-carotene production enhancement by UV-A radiation in Dunaliella bardawil cultivated in laboratory reactors. J Biosci Bioeng 2009;108(1):47-51.

11. Krishnakumar S, Bai VD, Rajan RA. Evaluation of bioactive metabolites from halophilic microalgae Dunaliella salina by GC - MS analysis. Int J Pharm Pharm Sci 2013;5:296-303.

12. Martinez G, Cifuentes A, Gonzalez M, Parra O. Effect of salinity on sexual activity of Dunaliella salina (Dunal) Teodoresco, strain CONC006. Rev Chil Hist Nat 1995;68:131-8.

13. Tsai C, Lu F, Hsu Y. Protective effects of Dunaliella salina - A carotenoids-rich alga - against ultraviolet B-induced corneal oxidative damage in mice. Mol Vis 2012;18:1540-7.

14. Hieber AD, King TJ, Morioka S, Fukushima LH, Franke AA, Bertram JS. Comparative effects of all-trans beta-carotene vs. 9-cis beta-carotene on carcinogen-induced neoplastic transformation and connexin 43 expression in murine 10T1/2 cells and on the differentiation of human keratinocytes. Nutr Cancer 2000;37(2):234-44.

15. Stanier RY, Kunisawa MM, Cohn- Bazire G. Purification and properties of unicellular blue green algae (order Chroococcales). Bacteriol Rev 1971;35(2):171-205.

16. Liang H, Ma A, Zhang P, Bi SL, Shi DY. Effect of ethanol extract of alga Laurencia supplementation on DNA oxidation and alkylation damage in mice. Asia Pac J Clin Nutr 2007;16 Suppl 1:164-8.

17. Kumar V, Bal A, Gill KD. Aluminum-induced oxidative DNA damage recognition and cell cycle disruption in different regions of rat brain. Toxicology 2009;264(3):137-44.

18. Bihaqi SW, Sharma M, Singh AP, Tiwari M. Neuroprotective role of Convolvulus pluricaulis on aluminium induced neurotoxicity in rat brain. J Ethnopharmacol 2009;124(3):409-15.

19. Ruperez FJ, Garcia-Martinez D, Baena B, Maeso N, Cifuentes A, Barbas $\mathrm{C}$, et al. Evolution of oxidative stress parameters and response to oral vitamins $\mathrm{E}$ and $\mathrm{C}$ in streptozotocin-induced diabetic rats. J Pharm Pharmacol 2008;60(7):871-8.

20. Tsakiris S, Schulpis KH, Marinou K, Behrakis P. Protective effect of L-cysteine and glutathione on the modulated suckling ratbrain $\mathrm{Na}^{+}, \mathrm{K}^{+}$-ATPase and $\mathrm{Mg}^{2+}$-ATPase activities induced by the in vitro galactosaemia. Pharmacol Res 2004;49(5):475-9.

21. Garg UC, Rai N, Singh Y, Dhaunsi GS, Sidhu GS, Ganguly NK, et al. A spectrophotometric method for calmodulin assay. Biotechniques 1988;6(4):294-6.

22. Barbareschi M, Caffo O, Veronese S, Leek RD, Fina P, Fox S, et al. $\mathrm{Bcl}-2$ and $\mathrm{p} 53$ expression in nodenegative breast carcinoma: A study with long-term follow-up. Hum Pathol 1996;27(11):1149-55.

23. Barakat-Walter I. Brain derived neurotrophic factor like immunore activity is localized mainly in small sensory neurons of rat dorsal root ganglia. J Neurosci Methods 1996;68(2):281-8.

24. Ahmed HH, Booles HF, Khalil WK, El-Ashmaoui HM, Othman SM. Possible therapeutic role of Jasonia candicans and Jasonia montana extracts in the regression of Alzheimer's disease in experimental model. Am J Biochem Biotechnol 2013;9:144-61.

25. Khalil WK, Booles HF. Protective role of selenium against overexpression of cancer-related apoptotic genes induced by o-cresol in rats. Arh Hig Rada Toksikol 2011;62(2):121-9.

26. El-Baz FK, Aly HF, Khalil WK, Booles HF, Saad SA. Jatropha curcas repairing effect on adhesion molecules, DNA damage and gene expression alteration in STZ-induced diabetic rats. Int J Pharm Bio Sci 2015;6:B198-214.

27. Stein TD, Johnson JA. Lack of neurodegeneration in transgenic mice over expressing mutant amyloid precursor protein is associated with increased levels of transthyretin and the activation of cell survival pathways. J Neurosci 2002;22(17):7380-8.

28. Luo Y, Bolon B, Damore MD, Fitzpatrick D, Liu H, Zhang J, et al. BACE1 (beta-secretase) knockout mice do not acquire compensatory gene expression changes or develop neural lesions over time. Neurobiol Dis $2003 ; 14(1): 81-8$.

29. Deng Y, Xu ZF, Liu W, Xu B, Yang HB, Wei YG. Riluzole-triggered GSH synthesis via activation of glutamate transporters to antagonize methylmercury-induced oxidative stress in rat cerebral cortex. Oxid Med Cell Longev 2012;2012:534705.

30. McLachlan DR, Wong L, Bergeron C, Baimbridge KG. Calmodulin and calbindin D28K in Alzheimer disease. Alzheimer Dis Assoc Disord 1987;1(3):171-9.

31. O'Day HD, Eshak K, Myred AM. Calmodulin binding proteins and alzheimer's disease. J Alzheimer's Dis 2015;46(3):553-69.

32. Jomova K, Valko M. Importance of iron chelation in free radical induced oxidative stress and human disease. Curr Pharm Des 2011;17(3):3460-73.

33. Qian ZM, Ke Y. Rethinking the role of ceruloplasmin in brain iron metabolism. Brain Res Brain Res Rev 2001;35(3):287-94.

34. Dantoine TF, Debord J, Merle L, Lacroix-Ramiandrisoa H, Bourzeix L, Charmes JP. Paraoxonase 1 activity: A new vascular marker of 
dementia? Ann N Y Acad Sci 2002;977:96-101.

35. Wehr H, Bednarska-Makaruk M, Graban A, Lipczyńska-Łojkowska W, Rodo M, Bochyńska A. Paraoxonase activity and dementia. J Neurol Sci 2009;283:107-8

36. Zengi O, Karakas A, Ergun U, Senes M, Inan L, Yucel D. Urinary 8-hydroxy-2'-deoxyguanosine level and plasma paraoxo-nase 1 activity with Alzheimer's disease. Clin Chem Lab Med 2011;50(3):529-34.

37. Bednarska-Makaruk ME, Krzywkowski T, Graban A, LipczyńskaŁojkowska W, Bochyńska A, Rodo M, et al. Paraoxonase 1 (PON1) gene-108C $>\mathrm{T}$ and p.Q192R polymorphisms and arylesterase activity of the enzyme in patients with dementia. Folia Neuropathol 2013;51(2):111-9.

38. Cervellati C, Romani A, Bergamini CM, Bosi C, Sanz JM, Passaro A, et al. PON-1 and ferroxidase activities in older patients with mild cognitive impairment, late onset Alzheimer's disease or vascular dementia. Clin Chem Lab Med 2015;53(7):1049-56.

39. Aly HF, Metwally FM, Ahmed HH. Neuroprotective effects of dehydroepiandrosterone (DHEA) in rat model of Alzheimer's disease. Acta Biochim Pol 2011;58(4):513-20.

40. Johnson VJ, Kim S, Sharma RP. Aluminum maltolate induces apoptosis and necrosis in neuro-2a cells: Potential role for $\mathrm{p} 53$ signaling. Toxicol Sci 2005;83(2):329-39.

41. Takuma K, Matsuo A, Himeno Y, Hoshina Y, Ohno Y, Funatsu Y, et al $17-\beta$ estradiol attenuates hippocampal neuronal loss and cognitive dysfunction induced by chronic restraint stress in ovariectomized rats. Neuroscience 2007;146(1):60-8

42. Nagatsu T, Mogi M, Ichinose H, Togari A. Changes in cytokines and neurotrophins in Parkinson's disease. J Neural Transm 2000;20(60):277-90.

43. Guix FX, Uribesalgo I, Coma M, Munoz FJ. The physiology and pathophysiology of nitric oxide in the brain. Prog Neurobiol 2005;76(2):126-52.

44. Dorheim MA, Tracey WR, Pollock JS, Grammas P. Nitric oxide synthase activity is elevated in brain microvessels in Alzheimer's disease. Biochem Biophys Res Commun 1994;205(1):659-65.

45. Platt B, Carpenter DO, Büsselberg D, Reyman KG, Riedel G. Aluminum impairs hippocampal long-term potentiation in rats in vitro and in vivo. Exp Neurol 1995;134(1):73-86.

46. Canales JJ, Corbalan R, Montoliu C, Liansola M, Monfort P, Erceg $\mathrm{S}$, et al. Aluminum impairs the glutamate- nitric oxide cGMP pathway in cultured neurons and in rat brain in vivo molecular mechanisms and implications for neuropathology. J Inorg Biochem 2001;87(1-2):63-9.

47. Lüth H, Holzer M, Gartner U, Staufenbiel M, Arendt T. Expression of endothelial and inducible NOS-isoforms is increased in Alzheimer's disease, in APP23 transgenic mice and after experimental brain lesion in rat: Evidence for an induction by amyloid pathology. Brain Res 2001;913(1):57-67.

48. Vassar R, Citron M. A ß-generating enzymes: Recent advances in $\beta$ - and $\gamma$-secretase research. Neuron 2000;27:419-22.

49. Xue KX, Wu JZ, Ma GJ, Yuan S, Qin HL. Comparative studies on genotoxicity and antigenotoxicity of natural and synthetic b-carotene stereoisomers. Mutat Res 1998;418(2-3):73-8.

50. Omenn GS, Goodman GE, Thornquist MD, Balmes J, Cullen MR, Gluss A, et al. Risk factors for lung cancer and for intervention effects in CARET, the beta-carotene and retinol efficacy trial. J Natl Cancer Inst 1998;88(21):1550-9.

51. Polozza P, Calviello G, Bartoli GM. Prooxidant activity of betacarotene under $100 \%$ oxygen pressures in rat liver microsomes. Free Radic Biol Med 1995;19(6):887-92 